\title{
FORMATION OF PROFESSIONAL COMPETENCE OF FUTURE TEACHERS IN THE EDUCATIONAL ENVIRONMENT OF THE HIGHER EDUCATION INSTITUTION
}

\section{ФОРМУВАННЯ ПРОФЕСІЙНОЇ КОМПЕТЕНТНОСТІ МАЙБУТНІХ ВЧИТЕЛІВ У ОСВІТНЬОМУ СЕРЕДОВИЩІ ЗАКЛАДУ ВИЩОЇ ОСВІТИ}

\section{Oksana Nozdrova ${ }^{1}$ \\ Irina Bartienieva ${ }^{2}$}

DOI: https://doi.org/10.30525/978-9934-588-38-9-11

\begin{abstract}
The article is devoted to the consideration of the problem of professional competence of future teachers, finding ways of its formation in higher education pedagogical institutions. The approaches of modern researchers to the definition of the concepts of «competence», «professional competence» are considered. The definition of «professional and pedagogical competence» is given, which contains complementary elements: instrumental components (knowledge, ability, activity independence, individuality) and personal qualities (tact, sociability, goodwill, emotional balance). The vast majority of scholars in the structure of pedagogical competence include the ability and experience of professional activity. They reveal the practical side of the teacher's work. It is emphasized that the structural elements of the process of training teachers with a competent approach are personal competencies - overcoming problems and stresses, tolerance, communicativeness, initiative, non-standard, argumentation and professional competencies. It is analyzed that in pedagogy and psychology of higher education the professional-pedagogical preparation of the future teacher as competent, capable for self-development is constantly being researched;
\end{abstract}

${ }^{1}$ Candidate of Pedagogical Sciences,

Associate Professor of the Department of Pedagogy,

State Institution «South Ukrainian National

Pedagogical University named after K.D. Ushynsky», Ukraine

${ }^{2}$ Candidate of Pedagogical Sciences,

Associate Professor of the Department of Pedagogy

State Institution «South Ukrainian National

Pedagogical University named after K.D. Ushynsky», Ukraine 
preparing of the future teacher to work in the context of educational reform; general principles of organization of pedagogical process and basic directions of constructing the content of psychological and pedagogical preparation, which ensures formation of teacher-researcher, who is in constant search for effective and rational methods of teaching and upbringing; formation of the creative personality of the future teacher; organization of professional self-education of future teachers. Instead, the problem of forming the professional competence of future teachers in the process of introducing pedagogical teaching technologies into the educational space of a higher education institution in scientific sources is not sufficiently covered. It is stated that the purpose of the article is to research the peculiarities of the future teacher's professional competence formation in the educational environment of higher education institutions, which is based on the identification of methodological approaches (systemic, activity, personality-oriented, acmeological and synergistic). Certain functions, structure and pedagogical teaching technologies for forming the professional competence of future teachers are determined, which are decisive in the system of professional education. Given these, significant results can be expected. The task of the research is formulated, which consists in the analysis of the determined methodological approaches and theoretical substantiation of the effectiveness of educational pedagogical technologies for forming the professional competence of the future teacher. The complex of methods of theoretical level was used, namely: analysis of psychological and pedagogical literature on the selected problem, systematization and generalization of the information received; empirical level: pedagogical observation, conversation, evaluation of products of creative activity.

It is revealed that the formation of professional competence in students is most effectively facilitated by the introduction of educational pedagogical technologies in the educational space during the study of discipline «Pedagogy» (educational technologies of cooperation organization; technologies of differentiated learning; technologies of organization of independent educational activity; game educational technologies; educational technologies of organization of project activity; technologies of achievement of obligatory educational results in the system of future teacher's professional training). It is noted that each of the above pedagogical teaching technologies in the program of the course «Pedagogy» was considered as a technological 
map that contained five interconnected components: purpose, motivational, content, procedural components and expected results. The organization of work of future specialists is presented: each student received an example of the technological card at the beginning of studying the modules ( $« \mathrm{Gen}-$ eral Fundamentals of Pedagogy», «History of Pedagogy», «Theory of Education», «Theory of Education») from the discipline «Pedagogy» and for him it was a targeted program that indicated, what has to be done. Each pedagogical educational technology is described for revealing ways of realization of individual educational trajectories of students in the process of professional training. In particular, the types of activities (play, problematic, differentiated, independent, etc.) that contributed to the formation of professional competence of future teachers are indicated. They encourage them to be capable of self-development, creativity, creative thinking, self-organization of their lives and highly productive professional activity.

The organization of the work provided the following results: is created a comfortable educational environment and conditions to meet the individual educational needs of the subjects of the educational process (teachers, students); students had the opportunity to choose their own priority teaching and pedagogical and interactive technologies; increased educational motivation of students; formed the skills of goal-setting, planning their activities, the ability to exercise self-control and self-esteem. It is planned to prepare methodological recommendations, to develop a cycle of training lessons with the introduction of technological maps of educational pedagogical technologies in the course of studying the discipline «Pedagogy» in the educational process of higher education; to outline promising tasks for reforming modern education with the help of modern interactive learning that will shape the student's key competences and expand his / her opportunities in choosing his / her own educational trajectory.

\section{1. Вступ}

Підготовка вчителя в умовах модернізації освіти та інноваційних педагогічних технологій у сфері фундаментальної відкритої й безперервної освіти - це підготовка педагога відповідного рівня й профілю; конкурентоздатного на ринку праці. У педагогічній літературі (С. Бондар, А. Маркова, О. Овчарук, Г. Скоробогатова, А. Хуторський, С. Шишов) правомірно визнається пріоритет компетентності як однієї 
3 головних характеристик особистості майбутнього вчителя, поряд 3 гуманізмом, демократизмом, духовною культурою, комунікативністю, організаторським талантом. Компетентність означає не лише належну поінформованість у широкому колі питань, а й відповідний стиль педагогічної діяльності, що грунтується на знаннях і практичному досвіду. Вона $є$ необхідною ланкою постійного вдосконалення вже набутого інтелектуального й практичного досвіду; необхідним щаблем до пошуку ефективних шляхів підвищення педагогічної майстерності й досягнення самобутності особистості [1, с. 126].

Аналіз наукової психолого-педагогічної літератури доводить існування різних точок зору на розуміння сутності професійно-педагогічної компетентності, яку інколи ототожнюють з педагогічною культурою, педагогічною освіченістю. Більшість дослідників розглядають професійно-педагогічну компетентність у двох аспектах: як мету освіти і професійної підготовки; як певний результативний стан, що характеризує рівень спеціаліста щодо реалізації особистих професійних повноважень.

Як свідчать численні педагогічні дослідження (В.І. Бондар, Л.В. Зиков, М.І. Жалдак, Л.М. Карамушка, В.I. Маслов, О.І. Пометун), професійно-педагогічна компетентність спеціаліста є більш широким формуванням і містить у собі взаємодоповнювальні елементи: інструментальні компоненти (знання, уміння, активність самостійність, індивідуальність) та особистісні якості (тактовність, комунікабельність, доброзичливість, емоційна врівноваженість). Переважна більшість учених до структури педагогічної компетентності включає вміння й досвід професійної діяльності. Саме вони розкривають практичний бік роботи вчителя. В абсолютній більшості досліджень основою цього поняття були визначені знання, які складають когнітивно-змістові аспекти діяльності, розкривають теоретичні основи професійної підготовки вчителя [4, с. 24].

У педагогіці та психології вищої школи неперервно досліджується професійно-педагогічна підготовка майбутнього вчителя як компетентного, здатного до саморозвитку; підготовка майбутнього вчителя до роботи в умовах реформування освіти; загальні принципи організації педагогічного процесу та основні напрями конструювання змісту психолого-педагогічної підготовки, що забезпечує формування 
вчителя-дослідника, який перебуває в постійному пошуку ефективних і раціональних методів навчання й виховання; формування творчої особистості майбутнього вчителя; організація професійного самовиховання майбутніх учителів. Натомість проблема формування професійно-педагогічної компетентності майбутнього вчителя в процесі впровадження педагогічних навчальних технологій в освітній простір закладу вищої освіти у наукових джерелах висвітлена недостатньо.

Отже, мета статті - дослідження особливостей формування професійної компетентності майбутнього вчителя шляхом впровадження в освітнє середовище навчальних педагогічних технологій.

Реалізація компетентнісного підходу передбачала не тільки накопичення у майбутніх вчителів нормативно визначених знань, умінь і навичок, а й формування, розвиток здатності діяти мобільно, креативно, використовуючи передовий педагогічний досвід у процесі навчання.

Спираючись на виокремленні методологічні підходи, ми визначили певні функції, структуру та педагогічні навчальні технології для формування професійної компетентності майбутніх вчителів, що є визначальними у освітньому середовищі. За умов їх врахування можна сподіватися на досягнення значних результатів.

Слід зазначити, що важливою складовою всіх рівнів розвитку професійної компетентності майбутніх вчителів була самоосвіта.

\section{2. Основні методологічні підходи до формування професійної компетентності майбутніх вчителів у освітньому процесі закладу вищої освіти}

Перед сучасними навчальними закладами постає завдання навчити людину самостійно оволодівати новими знаннями та інформацією, навчити вчитися, виробити потребу в навчанні впродовж життя. У XXI столітті отримання знань стає суттєвою рисою способу життя кожної людини. Вивчення впливу глобалізаційних процесів на розвиток неперервної освіти відображено в працях М. Згуровського, В. Кременя, Л. Лук'янової, Н. Ничкало. Важливе значення для дослідження проблем неперервної освіти мають праці з філософії освіти В. Андрущенка, Г. Васяновича, І. Зязюна, Н. Кузьміної, В. Лутая, Н. Лобанова, А. Новікова. Окремі аспекти неперервної професійної освіти розгля- 
дають Б. Громовик, Р. Гуревич, Т. Жидких, Г. Кільова, О. Титаренко та інші [2, с. 4]. Висвітлено основні засади щодо становлення професійної компетентності майбутніх вчителів у процесі професійної підготовки, поклавши в основу головний принцип освіти - гуманізацію, що постулює людину як вищу соціальну цінність, і гуманітаризацію, покликану формувати цілісну картину світу $[1$, с. 8]. Загальною стратегією пізнання особливостей професійної освіти було обрано методологічні підходи (системний, діяльнісний, особистісно зорієнтований, акмеологічний та синергетичний), які сприяли розвитку ідеї неперервної професійної освіти на новому рівні. На законодавчому рівні зазначено, що основою методології освіти XXI ст. повинні стати принципи науковості, гуманізації, демократизації, всебічного розвитку особистості, диференціації та інтеграції, інформатизації, фундаменталізації, наступності та неперервності тощо [4, с. 45].

Розглянемо їх детальніше в ході вивчення навчальної дисципліни «Педагогіка», адже студенти на практичних заняттях завжди здійснювали пошук нових технологій навчання, експериментували, спрямовуючи всі вектори освітньої роботи до найголовнішого - до якісних результатів.

Застосовуючи системний підхід, ми розглядали усі компоненти професійної діяльності майбутнього вчителя (професійно-змістовий, операційно-технологічний, професійно-особистісний, професійно-мотиваційний) у єдності закономірних взаємозв'язків, спираючись на загальну теорію керування складними динамічними системами [6, с. 74].

Адже системний підхід мав багато переваг: він збільшував точність розв'язання проблем різного роду; сприяв отриманню більш якісних результатів; здійснював синтез результатів, отриманих з різних дисциплін [2]. Ми зазначили, що самоосвітня діяльність майбутніх вчителів (складання плану самовдосконалення професійної компетентності; науково-дослідна робота; кооперативна професійна взаємодія з викладачами, студентами; збір і складання творчого портфоліо майбутнього педагога; організація майстер-класів) забезпечила якісні позитивні результати.

Діяльнісний підхід у навчальній діяльності полягав у формуванні у майбутніх вчителів уміння діяти. Діяльність людини розглядалася в загальному значенні цього слова - як динамічна система взаємодії 
людини із зовнішнім середовищем, а також у вузькому, конкретному як специфічна професійна, наукова, навчальна форма активності людини, у якій вона досягала свідомо поставлених цілей, що формувалися внаслідок виникнення певних потреб. Діяльність передбачала цілеспрямовану активність, яку спонукали або зовнішні обставини, або внутрішні мотиви особистості [2, с. 10]. Діяльнісний підхід зумовив комплексне використання у освітньо-виховному процесі ЗВО інноваційних технологій навчання, перенесення акцентів на інтерактивні форми та методи навчання.

На практичних заняттях з навчальної дисципліни «Педагогіка» використовувалися активні форми навчання : методи проектів, дослідницької діяльності («Ажурна пилка», «Карусель»), міні-модулі та інші, які спонукали студентів до самостійності та творчого пошуку. Було проведено анкетування студентів щодо визначення їх індивідуальних можливостей та потенціалу, виявлення шляхів реалізації індивідуальних освітніх траєкторій в умовах закладу вищої освіти; здійснено вхідний комплексний моніторинг готовності майбутніх фахівців до соціального й професійного самовизначення та самореалізації; організовано психолого-педагогічний супровід особистості, який був заснований на прагненні до досягнення цілей професійного становлення, планування кар'єри, культурного,соціального та освітнього рівня; круглий стіл «Індивідуальна траєкторія розвитку педагога: шляхи реалізації».

Організація проведеної роботи забезпечила наступні результати: було створено комфортне освітнє середовище та умови для задоволення індивідуальних освітніх потреб суб'єктів освітнього процесу (студентів, викладачів); студенти самостійно мали змогу обрати пріоритетні шляхи реалізації освітньої парадигми й прийняти оптимальне рішення з урахуванням формули вибору: «хочу - можу - треба»; підвищилася освітня мотивація студентів; в них було сформовано навички цілепокладання, планування своєї діяльності, вміння здійснювати самоконтроль і самооцінку.

Реалізація особистісно зорієнтованого підходу у освітньому процесі ЗВО визначило організацію професійної діяльності майбутніх вчителів на засадах всебічного врахування їх індивідуальних потреб і можливостей, ставлення до них як до свідомих і відповідальних суб'єктів освітньо-виховної взаємодії. Сутнісною характеристикою 
особистісно зорієнтованого навчання було створення умов для індивідуальної самореалізації, розвитку особистісних якостей, формування ціннісного світогляду. Освітній процес базувався на визнанні принципу педагогічної взаємодії, стимулюванні індивідуальної й колективної творчості [10, с. 34]. Система вищої освіти актуалізувала гуманістичну педагогіку, зорієнтовану на особистість. Охарактеризуємо іiі відмінні ознаки: зміщення пріоритетів на розвиток психічних, фізичних, інтелектуальних, моральних та інших сфер особистості замість оволодіння обсягом інформації й формування визначеного кола умінь і навичок; зосередження зусиль на формуванні вільної, самостійної особистості, громадянина, здатного робити обгрунтований вибір у різноманітних навчальних і життєвих ситуаціях [2, с. 7].

Технологія проведення студентами особистісно-орієнтованих уроків при проведенні «майстер-класів» на практичних заняттях мала таку структуру: створення привабливої мети; здивування; фантастична ситуація; ігрова навчальна діяльність; творчо-пошукова діяльність.

На етапі засвоєння, формування вмінь і навичок ми давали завдання на вибір: засобів навчальної діяльності (індивідуально, фронтально чи в групі; письмово або усно); засобів фіксації нового матеріалу (схема, план, таблиця, висновки тощо); завдань і способів їх виконання.

На цьому етапі уроку використовували такі методи: заохочення; навчально-пізнавальна гра; створення ситуації успіху, інтересу до навчання; проблемна ситуація: яскраві наочно-образні уявлення; ситуація взаємодопомоги; виконання творчих завдань тощо.

На нашу думку, контроль знань відбувався за допомогою: групових і парних форм взаємоконтролю й взаємоаналізу, самоаналізу й самоконтролю (виправлення студентами помилок у ході проведення міні-лекцій «провокацій», осмислення їх причин); взаємо- і самооцінювання (словесне, рейтингове тощо).

Національна стратегія розвитку освіти в Україні на період до 2021 року визначає пріоритетним проектування акмеологічного освітнього простору з урахуванням інноваційного розвитку освіти, запитів особистості, потреб суспільства й держави [8].

Це позитивна самореалізація фахівця, яка обов'язково передбачає адекватну самосвідомість, усвідомлення своєї соціальної ролі, значимості власної особистості, свого інтелекту, знання традицій, оціноч- 
них норм, цінностей своєї професійної сфери. Професійне акме - це психічний стан, у якому наявні максимальна змобілізованість, реалізованість усіх професійних здібностей, можливостей і резервів людини на конкретному етапі життя; це кульмінація, пік у професійному розвиткові людини [4, с. 48].

Професіоналізм розглядаємо як інтегральну психологічну характеристику фахівця, яка відображає рівень та характер оволодіння обраною професією, досягнення високої результативності праці, ефективне виконання посадових обов'язків у взаємодії з іншими людьми. Тому поняття професіоналізму охоплює три аспекти праці - професійну діяльність, професійне спілкування та особистість фахівця [7].

Використання акмеологічних технологій в освіті передбачало створення в освітньому процесі закладів вищої освіти умов для комплексної активізації резервних можливостей особистості майбутніх педагогів. Це розвиток саморегуляції студентів (здатність людини керувати собою на основі сприйняття й усвідомлення актів своєї поведінки та психічних процесів), рефлексії (процес самопізнання суб'єктом внутрішніх психічних актів і станів) та креативності (творчі здібності індивіда, що характеризувалися здатністю до продукування принципово нових ідей) [7, с. 10].

Синергетична модель освіти, яку застосовували у становленні професійної компетентності майбутніх вчителів на рівні взаємовідносин студентів і викладачів характеризувалася такими якостями: відкритістю освітнього процесу й змісту навчального матеріалу для інновацій, які могли запропонувати не лише викладачі, а й студенти; творчим характером навчання й виховання ; переходом від переважної орієнтації на відтворювальні навчальні завдання до орієнтації на продуктивну теоретичну й практичну діяльність; рівноправними суб'єкт-суб'єктними взаємовідносинами викладача й студентів, спрямованими на розвиток й пізнання; дотриманням принципів індивідуального підходу до студентів зі спрямованістю освітньо-виховної роботи на їх самоосвіту, самовиховання, самореалізацію; звільнення викладача й студента від стереотипів і педагогічних догм у організації та змісті освітнього процесу [2, с. 11].

Синергетичний підхід у становленні професійної компетентності майбутніх вчителів у процесі професійної підготовки передбачав реа- 
лізацію низки інновацій, серед яких найважливішими вважали такі: самоосвіта, інтерактивне навчання,особистісно-зорієнтоване навчання, формування системно-креативного мислення, виявлення потенціалу та перспективних тенденцій власного розвитку.

\section{3. Використання педагогічних навчальних технологій у процесі викладання навчальної дисципліни «Педагогіка»}

\section{у закладах вищої освіти}

Формування в майбутніх учителів основ професійної компетентності значною мірою залежить від кваліфікації та педагогічної майстерності викладача, його ерудиції, наукової та методичної творчості. Відповідно до цього у діяльності викладача вищої школи можна виділити два етапи: проектування і реалізації навчального процесу. Етап проектування може бути пов'язаний з конструюванням технологічних карт, які В. Монахов називав «паспортом проекту наступного навчального процесу» [7, с. 37].

Наводимо зразки навчальних педагогічних технологій, які ми використовували при вивченні навчальної дисципліни «Педагогіка» у закладах вищої освіти.

Сутність навчальних технологій - відобразити структурні елементи, щоб допомогти майбутньому вчителеві оволодіти методикою їх застосування для подальшого використання в практичній діяльності.

Незважаючи на розмаїття підходів до класифікації навчальних технологій (В.П. Беспалько, М.В. Кларин, Г.К. Селевко, Т.С. Назарова, О.М. Пєхота, В.Ю. Пітюков та ін.), викладач ЗВО має прагнути зорієнтувати майбутнього вчителя у їх правильному виборі [7, с. 38].

Так, під час проведення практичних занять 3 курсу «Педагогіка» було виділено такі навчальні технології, теоретичним підгрунтям яких була особистісно орієнтована освіта, спрямованість навчання на системно-діяльнісний, акмеологічний, синергетичний підходи; які були побудовані на розвиток потенціалу студентів, здатних проектувати свою навчальну діяльність і бути ії активними суб'єктами.

\section{1. Навчальні технології організації співробітництва.}

Особливістю цих технологій була побудова навчання на основі активної взаємодії всіх учасників освітнього процесу з використанням різноманітних засобів інформації. 
2. Технології диференційованого навчання дали змогу створити умови для залучення кожного студента до навчальної діяльності відповідно до його індивідуальних можливостей.

3. Технології організації самостійної освітньої діяльності. Пріоритетними завданнями цієї технології було навчання студентів умінню визначати мету й самостійно організовувати свою діяльність для іiі досягнення.

4. Ігрові навчальні технології. Характерною рисою цієї технології була побудова навчального процесу шляхом заохочення студентів до гри.

5. Навчальні технології організації проектної діяльності. Ці технології були орієнтовані на самостійну пошуково-творчу діяльність студентів як індивідуальну, так і групову. У процесі проектної діяльності студенти вчилися не тільки здобувати знання, а й засвоювати та застосовувати їх на практиці.

6. Технології досягнення обов'язкових навчальних результатів у системі професійної підготовки майбутнього вчителя. Впровадження цих технологій забезпечувало реалізацію двох стратегічних гуманістичних цілей: створення комфортних умов для навчання студентів і здійснення професійної діяльності.

Кожна з розглянутих вище педагогічних навчальних технологій у програмі курсу «Педагогіка» розглядалася як технологічна карта. У роботі ми спиралися на дослідження Л. Коваль щодо структури технологічної карти, яка містила п'ять взаємопов'язаних складових: мета, мотиваційний, змістовий, процесуальний компоненти та очікувані результати [7, с. 40].

Мета - це знання і вміння, які необхідно сформувати у майбутнього вчителя під час засвоєння тієї чи іншої навчальної технології.

Мотиваційний компонент спонукав майбутнього вчителя до регуляції своєї поведінки та засвідчував його свідоме ставлення до впровадження навчальних технологій у практику загальноосвітньої школи. Для оцінювання ступеня наповненості, змістовності та активності мотиваційного компоненту як критеріальних показників слід визначити два основних: наявність у майбутнього вчителя пізнавального інтересу й виявлення особистісно значущого змісту готовності.

Змістовий компонент професійної діяльності майбутнього вчителя характеризувався обсягом знань, їх глибиною, системністю, стилем мислення. Мотиваційний і змістовий компоненти передбачали стратегію професійної поведінки майбутнього вчителя у процесі професійної підготовки. 
Процесуальний компонент характеризувався можливістю реалізації цієї стратегії. Його основними критеріальними показниками було: наявність у майбутнього вчителя системи вмінь, необхідних для успішного формування готовності до впровадження навчальних технологій у практику загальноосвітньої школи. Крім того, процесуальний компонент орієнтував на усвідомлення й аналіз власної професійної діяльності.

Очікувані результати як блок технологічної карти, відображав наявність знань і вмінь, здатних вирішувати професійні завдання щодо впровадження сучасних навчальних технологій у практику загальноосвітньої школи [7, с. 38]. Зразок технологічної картки отримував кожний студент на початку вивчення модулів («Загальні основи педагогіки», «Історія педагогіки», «Теорія навчання», «Теорія виховання») 3 навчальної дисципліни «Педагогіка». Для нього вона була цільовою програмою, яка вказувала на те, що потрібно робити. Але, як це зробити ефективно, студент вирішував самостійно.

\section{4. Шляхи формування професійної компетентності майбутніх} вчителів при вивченні навчальної дисципліни «Педагогіка».

Охарактеризуємо стисло кожну педагогічну навчальну технологію щодо виявлення шляхів реалізації індивідуальних освітніх траєкторій студентів в процесі професійної підготовки.

\section{1. Технології організації самостійної освітньо-виховної діяльності}

У ході викладання педагогічних дисциплін впроваджували навчально-рольові ігри: мікровикладання, рольові диспути, рольові ігри, авторські фільми.

Мікровикладання. Студентові, який виконував роль «учителя», пропонували викласти фрагмент уроку для будь-якого класу (модуль «Теорія навчання»). Наукову інформацію студент повинен був опрацювати, переробити й подати iі у доступній та зрозумілій формі. При цьому необхідно було максимально передати науковий зміст інформації, враховуючи вікові можливості, життєвий досвід, рівень знань учнів. Роль «учнів» виконували студенти групи, виняток становили експерти, функцією яких був аналіз ситуації. 
У процесі підготовки до мікровикладання «вчителеві» дозволялося попередньо попрацювати з класом 3 метою виявлення рівня знань 3 теми заняття. В ході проведення уроку «учні» повинні були відповідати на запитання на рівні програми загальної середньої школи. «Експерти» оцінювали дослідницькі уміння «вчителя», а також знання студентами програми даного класу, психологічних особливостей учнів цього віку.

Крім того, студент міг виступати в ролі дублера викладача на практичних заняттях. Матеріалом для гри були певні ситуації, в яких студентові-дублеру необхідно було викладати один і той же матеріал різними методами: за допомогою усної розповіді, частково-пошукового методу, організації самостійної роботи студентів. У цьому випадку ми звертали увагу на оригінальність, послідовність, повноту проблемних питань, які ставив дублер перед студентами групи.

Під час проведення практичних занять дублер міг вимагати від студентів використання наукового матеріалу у вигляді: логічних схем, графіків, алгоритмів; зміни тексту з використанням різних видів унаочнення - символічного, інструктивного, схематичного, художнього; складання варіантів питань 3 орієнтацією на різні групи «учнів», які відрізнялися якістю знань, самостійністю мислення, схильністю до різних видів діяльності; розробки методики побудови проблемної ситуації; проведення аналізу причин ускладнень, які виявляли в «учнів» (студентів) під час вивчення нової теми.

Авторські фільми. Розвиткові дослідницьких умінь значною мірою сприяла така форма роботи, як створення авторських фільмів. Авторські фільми ми відносили до самостійної творчої роботи студентів, яка виконувалась індивідуально або творчою групою.

Тривалість фільму не обмежувалася часом, його можна було коментувати (автор або ведучий). Головною метою авторського фільму було наочне відображення проблеми та шляхів іiї вирішення, якщо це можливо.

Перед зйомками фільму студенти вивчали теоретичний аспект проблеми: писали сценарій; проводили пошук об'єкта, що розглядався; вивчали місце зйомок, а потім знімали фільм за сценарієм, переглядали матеріал, озвучували фільм. Робота над авторським фільмом дозволила студентам виявити такі дослідницькі уміння: нестандартно вирішувати проблеми; долати інерцію мислення; генерувати ідеї; фантазувати, уявляти; моделювати, прогнозувати тощо. 


\section{2. Технології диференційованого навчання}

Особливістю цієї технології було те, що вона забезпечувала творчу ініціативу, високу внутрішню мотивацію у процесі виконання проектної роботи. Значно збільшувалася інтенсивність засвоєння знань, умінь та досвіду ділових відносин. Поряд з аналітико-синтетичними (вміння аналізувати, систематизувати, узагальнювати) та прогностичними (вміння аналізувати та прогнозувати дії, майбутні рішення тощо) у майбутнього вчителя розвивалися креативні вміння. Саме під час проектної роботи студент краще усвідомлював права та обов'язки вчителя, оволодівав елементами таких професійно-ділових відношень, як уміння доводити, переконувати, вислуховувати протилежні аргументи, відстоювати чи змінювати свою точку зору, давати оцінку діям, вміти робити висновки тощо. Для проектної роботи 3 курсу «Педагогіка»( модуль «Теорія виховання») за темою «Екологічне виховання учнів» у формі захисту проектів «міст (мікрорайонів) майбутнього» обиралися: групи студентів, які виконували ролі архітекторів міст (районів) майбутнього (5 осіб); студентів групи, які виступали у ролі санітарного лікаря, працівників садово-паркової служби; студентів, які виконували ролі кореспондентів журналів та газет; ведучих, які виступали 3 короткими історичними оглядами 3 обраної теми. Таким чином, проектна робота охоплювала всіх членів студентської групи.

У ході підготовки проекту складався план і сценарій. У вступній частині ведучі висвітлювали питання:

1) Iсторія розвитку міст в різні епохи. Метою виступу була демонстрація того, що забудівля міст визначалася соціальними відношеннями, географічними умовами, технічними та економічними можливостями, уявою про красу, моду, престиж.

2) Розвиток урбанізації на сучасному етапі. Провідною думкою виступу було те, що місто - це залежна екосистема й ці обставини вкрай загострювали екологічні проблеми міст.

3) Промислове забруднення міської екосистеми - найнебезпечніше для життя людини. Метою виступу була демонстрація загрози промислових забруднень. У ході цих виступів ведучі обов'язково використовували різні види унаочнення: репродукції картин художників минулого та сучасності, фрагменти документальних фільмів. 
Наступна група презентувала фантастичний проект. Студенти створювали штучні острови або плавучі міста в океані. Вони також використовували ідеї письменників-фантастів, але додаючи елементи свого бачення й вирішення проблеми. В цих проектах зверталася увага на питання енергопостачання, забудівлі території, транспорту у місті та його використання; звідки населення буде отримувати питну воду і продукти харчування; як буде вирішено проблему переробки відходів; як вирішуватиметься проблема зайнятості населення, а також як людина міста «майбутнього» буде спілкуватися з природою.

Цікаво проходила презентація проекту «Квартира як екологічна система». В цьому проекті студенти виділяли наступні положення: квартира - місто в мініатюрі; роль автотрофів; характеристика фауни; побутова хімія, санітарний стан і значення джерел забруднення квартири; вирішення проблеми води та енергії в квартирі; проблема відходів.

Досвід проведення проектної роботи свідчив про підвищений інтерес у студентів до проблеми, їхню активність на всіх етапах підготовки й проведення проекту, де вони виступали як спільнота дослідників.

\section{3. Ігрові технології навчання}

Динамічні пари - цей метод проведення заняття полягав в тому, що студенти працювали в парі один з одним (по черзі - роль вчителя, роль учнів). Його застосування сприяло оволодінню студентами навичок співробітництва, вмінь висловлюватись та активно слухати.

Працюючи парами, студенти мали дотримуватись таких правил: прочитати завдання та вказівки щодо його виконання; визначити, хто говоритиме першим; по черзі висловити свою думку щодо проблеми; дійти спільної думки [11, с. 38].

Найбільший інтерес до роботи динамічними парами студенти виявляли на практичних заняттях із закріплення та повторення навчального матеріалу з навчальної дисципліни «Педагогіка». Викладач розробляв картки, які містили 2-3 практичні завдання з теми, що вивчалася. Одержавши картку, пара студентів перше завдання виконувала спільно. При цьому один пояснював другому, як його виконувати, а другий слухав, ставив запитання або висловлював своє розуміння. Друге й третє завдання студенти виконували самостійно, занотовуючи їх в зошити, а потім перевіряли один одного, коментуючи помилки. 
Пари не були постійними. За бажанням студент міг приєднатися до будь-якої іншої пари з правом слухати, спостерігати, втручатися у розв'язання завдання чи консультувати цих студентів за їх згодою або на прохання.

Студенти оволодівали мистецтвом пояснювати, доводити, запитувати, відповідати. Навчаючи іншого, студент-учитель не тільки краще запам'ятовував, розумів матеріал, а й відчував потребу грунтовніше вивчити тему.

Ігрові форми проведення занять були різноманітними. Наприклад, карткове педагогічне лото. 3 теми або навіть із цілого розділу («Загальні основи педагогіки») виготовлялися картки, одна 3 яких могла містити лише одне слово (тезаурус курсу), до якого необхідно було підібрати визначення.

Кожний студент із пари одержував 5-6 таких карток з різними завданнями. Розмістивши їх на столі, студенти по черзі вказували один одному, на яку слід відповідати. Якщо відповідь правильна, картку відкладали; якщо вона не задовольняла партнера, картка залишалася в того, хто відповідав. Переможцем ставав той, у кого картки закінчувалися раніше або їх залишилося менше, ніж в іншого. Отже, працюючи парами, студенти мали змогу пояснювати один одному, співпрацювати між собою, здобуваючи й удосконалюючи педагогічні вміння та навички, тобто у процесі гри навчалися один в одного. Водночас це була чудова форма закріплення й повторення навчального матеріалу, а також підготовки до заліків та іспитів.

\section{4. Навчальні технології організації співробітництва}

Мозковий штурм. Це був ефективний метод колективного обговорення й пошуку рішень, що активізував уяву та творчість усіх учасників гри, сприяючи якнайшвидшому правильному розв'язанню складної психолого-педагогічної ситуації.

Гра проводилася за такими правилами: 1) команди мали запропонувати якомога більше ідей з розв'язання проблеми; 2) гравці жодної ідеї не відкидали лише тому, що вона суперечила загальноприйнятій думці; 3) не можна було обговорювати й критикувати висловлювання інших та оцінювати запропоновані ідеї;. 4) вибирати потрібно було ту ідею, яка, на думку групи, була правильною [11, с. 67]. 
Підсумки «мозкового штурму» підбивав викладач, оцінюючи ефективність роботи кожної групи.

Оскільки метод мозкового штурму використовували як фрагмент заняття, він займав мінімум часу (10-15 хвилин). Студентів поділяли на мікрогрупи з 3-5 осіб. Кожній ставилося запитання, на яке треба дати відповідь упродовж однієї хвилини. Наприклад, прокоментуйте вислів І.П. Павлова: «Позитивні емоції тонізують роботу півкуль, негативні - гальмують, пригнічують. Позитивні емоції - потужні пробуджувачі й натхненники людської діяльності» [11].

Ця методика мала певні переваги: по-перше, це був найемоційніший варіант гри; по-друге, у студентів виникав інтерес до активного продукування ідей, вони мали обгрунтовувати свою думку в процесі дискусії.

\section{5. Технології досягнення обов'язкових навчальних результатів у системі професійної підготовки майбутнього вчителя}

Наведемо зразок використання індивідуальних навчально-дослідних завдань для самостійної роботи студентами, що передбачало складання: концептуальних карт; опорних блок-схем лекції; кросвордів, тестів 3 теми; переліку визначень ключових понять курсу з посиланням на джерела; анотування статей (5-6 з однієї теми курсу), книги або окремих розділів, що пов'язані з темою; написання рефератів, тез, ece, доповідей за визначеними викладачем темами; різноманітні групові завдання, що передбачали розв'язання або підготовку проблемних ситуацій; діагностичних тестів, тесту-самооцінки професійно-педагогічної діяльності студента. Науково-дослідна робота студентів випливала із завдань навчальної дисципліни «Педагогіка» й сприяла розвитку їх творчих здібностей та дослідницьких умінь.

\section{5. Висновки}

Інтеграція України у світовий простір ставить перед суспільством завдання - створити таку систему освіти нового покоління, яка буде відповідати викликам нового тисячоліття, забезпечувати загальноцивілізаційний розвиток нової генерації - людей інформаційної епохи, здатних мислити й діяти системно, креативно.

Саме ці пріоритети лежать в основі реформування сучасної освіти, головне завдання якої - підготувати компетентну особистість, здатну 
знаходити правильні рішення у конкретних навчальних, життєвих, у майбутньому професійних ситуаціях, готову обирати демократичні принципи співіснування.

Сьогодення потребує лідерів нової формації. Людей компетентних, відповідальних, здатних мислити неординарно. Проблема виховання молодих лідерів - це проблема підготовки людини майбутнього, людини, яка відповідає вимогам XXI століття. Ще однією особливістю інновацій в освіті $\epsilon$ - застосування технологічних «ноу-хау» - пошук пілотних майданчиків для впровадження інновацій, докорінна зміна форм і методів навчання - перехід до освіти за компетентностями; орієнтація на освітні стандарти СС.

Організація проведеної роботи забезпечила наступні результати: створено комфортне освітнє середовище та умови для задоволення індивідуальних освітніх потреб суб' єктів освітнього процесу (викладачів, студентів); студенти самостійно мали змогу обрати пріоритетні інтерактивні технологіі; підвищилася освітня мотивація студентів; сформовано навички цілепокладання, планування своєї діяльності, вміння здійснювати самоконтроль і самооцінку.

Комплексне використання у освітньому процесі інноваційних технологій навчання, перенесення акцентів на інтерактивні форми та методи навчання, кооперативна професійна взаємодія з одногрупниками, збір і складання творчого портфоліо, організація майстер-класів та міні-лекцій) забезпечила якісні позитивні результати.

Планується підготувати методичні рекомендації, розробити цикл тренінгових занять 3 впровадження інтерактивної моделі навчання в освітній процес вищої школи, окреслити перспективні завдання 3 реформування сучасної освіти за допомогою інтерактивного навчання, яке зорієнтує та сформує ключові компетентності, які значно розширять можливості студента у виборі власної освітньої траєкторії.

\section{Список літератури:}

1. Авраменко К.Б. Компетентність викладача вищої школи як важлива складова його професіоналізму. Професіоналізм викладача вищої школи: освітні технології : Матеріали Міжнародної науково-практичної конференції. Миколаїв : Вид-во «ІЛЮН», 2004. С. 124-128.

2. Андрущенко В. Філософія освіти XXI століття: у пошуках перспективи. Філософія освіти. Київ : Майстер-клас, 2006. № 1(3). С. 6-12. 
3. Балашова С. Навчально-рольова гра у формуванні дослідницьких умінь студентів. Початкова школа. 2005. № 6. С. 52-55.

4. Вакуленко В. Загальна характеристика акмеології як науки й сфери практичної діяльності : зб. наук. праць. Вісник Інституту розвитку дитини. 2010. Вип. 10. С. 43-49.

5. Глузман О.В. Базові компетентності: їхня сутність та значення у життевому успіху. Гуманітарні науки. 2010. № 1. С. 7-11.

6. Євтух М.Б. Забезпечення якості вищої освіти - важлива умова інноваційного розвитку держави і суспільства. Педагогіка $i$ психологія. 2008. № 1(58). C. 70-74.

7. Коваль Л. Технологічні карти у професійній підготовці майбутнього вчителя початкової школи. Початкова школа. 2005. № 5. С. 37-42.

8. Національна стратегія розвитку освіти в Україні на період до 2021 року. URL: http:/www.zakon.rada.gov.ua/go/344/2013

9. Сисоєва С. Підготовка вчителя до формування творчої особистості учня: Монографія. Київ : Поліграф. книга, 1996. 40 с.

10. Шишов С. Понятие компетенции в контексте качества образования. Стандарты и мониторинг в образовании. 1999. № 2. С. 23-24.

11. Щербань П.М. Навчально-педагогічні ігри у вищих навчальних закладах : навч. посіб. Київ : Вища школа, 2004. 207 с.

\section{References:}

1. Avramenko K.B. (2004). Kompetentnist' vykladacha vyshchoyi shkoly yak vazhlyva skladova yoho profesionalizmu [The competence of a high school teacher as an important component of his professionalism]. Profesionalizm vykladacha vyshchoyi shkoly: osvitni tekhnolohiyi - High School Teacher Professionalism: Educational Technologies: Proceedings of the International Scientific and Practical Conference (pp. 124-128). Mykolaiv: Issue of «ILYUN». (in Ukrainian)

2. Andrushchenko V. (2006). Filosofiya osvity XXI stolittya: u poshukakh perspektyvy [The philosophy of education of the 21 st century: in search of perspective]. Filosofiya osvity - The philosophy of education, no. 1(3), pp. 6-12. Kyiv: Master Class. (in Ukrainian)

3. Balashova S. (2005). Navchal'no-rol'ova hra u formuvanni doslidnyts'kykh umin' studentiv [Educational role-play in the formation of students' research skills]. Pochatkova shkola - Elementary School, no. 6, pp. 52-55. (in Ukrainian)

4. Vakulenko V. (2010). Zahal'na kharakterystyka akmeolohiyi yak nauky y sfery praktychnoyi diyal'nosti [General characteristics of acmeology as a science and sphere of practical activity]. Visnyk Instytutu rozvytku dytyny - Bulletin of the Institute for Child Development, vol. 10, pp. 43-49. (in Ukrainian)

5. Gluzman O.V. (2010). Bazovi kompetentnosti: yikhnya sutnist' ta znachennya u zhyttyevomu uspikhu [Basic competences: their essence and importance in life success]. Humanitarni nauky - Humanities, no. 1, pp. 7-11. (in Ukrainian)

6. Yevtukh M.B. (2008). Zabezpechennya yakosti vyshchoyi osvity - vazhlyva umova innovatsiynoho rozvytku derzhavy i suspil'stva [Quality assurance in 
higher education is an important condition for innovative development of the state and society]. Pedahohika i psykholohiya - Pedagogy and psychology, no. 1(58), pp. 70-74. (in Ukrainian)

7. Koval L. (2005). Tekhnolohichni karty u profesiyniy pidhotovtsi maybutn'oho vchytelya pochatkovoyi shkoly [Technological maps in the professional training of the future teacher of elementary school]. Pochatkova shkola - Elementary school, no. 5, pp. 37-42. (in Ukrainian)

8. Natsional'na stratehiya rozvytku osvity v Ukrayini na period do 2021 roku [National Strategy for the Development of Education in Ukraine until 2021]. zakon.rada.gov.ua. Retrieved from: http:/www.zakon.rada.gov.ua/go/344/2013 (in Ukrainian)

9. Sysoeva S. (1996). Pidhotovka vchytelya do formuvannya tvorchoyi osobystosti uchnya [Preparing a teacher for the formation of a student's creative personality]. Kyiv: Polygraph. Book (in Ukrainian)

10. Shishov S. (1999). Ponyatiye kompetentsii v kontekste kachestva obrazovaniya [The concept of competence in the context of the quality of education]. Standarty $i$ monitoring $v$ obrazovanii - Standards and monitoring in education, no. 2, pp. 23-24. (in Russian)

11. Shcherban P.M. (2004). Navchal'no-pedahohichni ihry u vyshchykh navchal'nykh zakladakh [Educational-pedagogical games in higher education]. Kyiv: High School. (in Ukrainian) 